\title{
First-Year College Students' Experiences in the EFL Flipped Classroom: A Case Study in Indonesia
}

\section{Zamzami Zainuddin}

Faculty of Education and Teacher Training, Universitas Islam Negeri Ar-Raniry, Banda

Aceh, Indonesia,zem.aceh@gmail.com

The present study aimed to identify the first year college students' learning and experiences in an EFL flipped classroom at the State Islamic University of ArRaniry in Indonesia. 27 students who enrolled in English 2 course participated as samples of this study. The data were collected from diverse sources including questionnaire surveys, focus group discussion, individual interview and observation. The quantitative data responses were analyzed in column charts with the percentage, Mean and Standard Deviation while the interview analysis used a step-wise design described by Patton (2002). The process consisted of three steps: (1) Assemble the raw case; (2) Construct the case record and (3) Report a final case. Results designated that students engaged in the EFL flipped classroom environment through hands-on activities and peer work. This instruction also successfully enhanced students' enthusiasm for learning the content before coming to the class, provided more opportunities for interaction among peers, came to class prepared and obtained immediate instructor's feedbacks. All in all, the categories revealed that the majority of students perceived the flipped classroom highly positive. In this study, the researcher concluded that the students had successfully achieved six levels of cognitive domain of Taxonomy or higher-level learning of Bloom's Taxonomy.

Key Words: flipped classroom, EFL, Bloom's Taxonomy, experience, interaction, engagement, video lectures

\section{INTRODUCTION}

Technological Advancements have transformed the style of teaching-learning activities from the passive learning to the active learning, from the traditional instruction to the contemporary innovative instruction, and produced students from passive listeners to active learners. According to Wang and Heffernan (2010), the use of the traditional learning approach which focuses on the instructor as the center of knowledge is irrelevant in today's digital age. The traditional classroom activities such as lectures, labs, homework, and exams can be transferred to the website or video and students may access them everywhere even outside the class hour. In addition, many free learning 
materials have also been provided on the websites for learning sources and allowed students to access to a wide variety of free contents or sources. Zainuddin and Halili (2016) argued that in today's digital age, every student can access unlimited learning resources such as YouTube, TED-Ed, BBC News, or Khan Academy. This positive impact of technology growth has influenced the development of instructional technology in education and replaced the use of blackboard with online video lectures (Baepler, Walker, \& Driessen, 2014).

In the field of teaching a foreign language, using technology media is not a new method since it had been implemented several decades ago and impacted on students' effective learning (Wang \& Heffernan, 2010). In improving the quality of English language teaching, numerous studies have been reported regarding the use of technology such as video lectures. For example, İlin, Kutlu, and Kutluay (2013) reported that teaching English is a process where the students need to learn step by step to follow the process and need to practice a lot. They recommended using digital devices in teaching English (e.g., video and website), where the students can practice English independently at their own pace, not only in the classroom but also after the class hours. Zainuddin and Halili (2016) summarized that the flipped classroom approach is an innovative instruction and emerging technology in teaching-learning activities which has been implemented worldwide in various fields of study.

Base on this background, an English instructor at the State Islamic University of ArRaniry has attempted to implement the innovative instruction in teaching-learning process by flipping the class. In this case, the instructor shared the video lessons on the Blog and students watched them before attending class, whereas classroom activities were spent for hands-on and group discussion. Since the flipped learning instruction was firstly implemented at this college, the researcher attempted to report the phenomena of the students' first experience and perceptions during learning in the EFL flip-class environment.

\section{Flipped classroom}

Flipped classroom is an instructional strategy to learning activity where the students learn new materials outside of class and establish interactive discussion in the class (Zainuddin \& Attaran, 2015). In the flipped classroom instruction, the students learn through hands-on learning activities in the class and limited time is dedicated to lectures; this means that students use class time for real world activities to solve problems and discussion. The instructors in the flip-class use their productive time to facilitate students' active learning without wasting time to explain the content in front of the class. Halili and Zainuddin (2015) mention that by flipping the class, the instructor will not sacrifice a valuable class time needed for coverage of content. In other words, students watch online lectures at home, collaborate and interact in online discussions, and engage in classroom activities with the guidance of the instructor.

In the flipped classroom instruction, face to face traditional lecture in the classroom is transferred to the video and the students may review the content outside the classroom (Bergmann \& Sams, 2014). The video is one of the significant tools in the flipped 
classroom instruction. Therefore, the instructors may firstly prepare the tools to record the video lessons such as creator video software or typical video camera. Then, the instructors begin to record themselves explaining the subject. The instructor should create the video as attractive as possible to gain student interest to watch. Besides recording themselves on the video and to save the time, the instructor may use another alternative way by adopting short video lecture from various free websites such as Khan Academy or YouTube; this will save much of the instructor's time in recording the video. The video can be shared by uploading to the Web 2.0 tools such as Blogs, Wikis, YouTube, Facebook, or Twitter; students can then watch or download the video lesson on their preferred time outside the class hours.

\section{The use of a Blog in teaching English}

A Blog is a personalized website where users can post text, video, pictures, and the visitor may leave comments or questions. Students can follow their own learning activities by using a Blog such as reading, writing, learning, discussing, asking questions they do not understand and debating on any topics. Blogger (https://www.Blogger.com) is one of free Blog hosting that can be used for teaching-learning activities. In terms of teaching English by using a blog, Wan and Tan (2011) conducted a study to investigate students' perceptions of using Blog in English language class, the findings revealed that the majority of students enjoyed using a Blog in learning English and they could collaborate with each other to solve problems. Therefore, in this study, a Blog was chosen as a free online platform to share the video lessons and establish online interaction outside the class hours. Besides, students can follow their own learning activities by using Blog such as reading, writing, learning, discussing, asking questions, and debating on any topics. Various materials can be distributed on the Blog such as essay, video, and audio files that might be linked by visitors. The reason for choosing a Blog as an online platform in this study as it has been familiar to students of the research area.

\section{Theoretical frameworks}

This study was implemented based on the theory of Cognitive taxonomy of Bloom. Cognitive domain refers to students' knowing; this domain is focused on students' knowledge, comprehension and critical thinking (Scott, 2003). The taxonomy for cognitive domain provides six levels of learning. This explanation is arranged from the lowest level (Knowledge and Comprehension) to the highest level of cognitive domains (Application, Analysis, Synthesis, and Evaluation) (Bloom, 1956).

The present study was to explore the case of implementing the flipped classroom in teaching EFL at the State Islamic University of Ar-Raniry in Indonesia and to examine its pedagogical potential in language education. Hence, the following research questions that guided this work are as follows:

(1) How familiar are the students with technological devices in teaching-learning activities?

(2) How do the instructors apply the flipped classroom in teaching English? 
(3) What are students' experiences and perceptions of learning English in the flipped classroom?

\section{METHOD}

This study was conducted to study the case of students in the flipped classroom at the State Islamic University of Ar-Raniry in Indonesia. Both quantitative and qualitative methods were employed to collect the data from multiple sources and to obtain in-depth information about the implementation of flipped classroom instruction in a bounded space. A questionnaire survey, focus group discussion, individual interviews, and observation were used to assemble the data. The course of this study was English 2, a compulsory course for all undergraduate students in the first academic year. 27 undergraduate students who enrolled in English 2 class were selected as samples of this study. All participants were from English Department, Faculty of Education and Teacher Training, the State Islamic University of Ar-Raniry. In selecting the sample, the researcher used a purposeful sampling (a non-random sampling) since it explored a specific time, place, group, community, and person. Therefore, as recommended by Creswell (2013) that the researcher should get away from the random sampling in conducting a case study. Again, non-probability purposive sampling or criterion sampling was used since the target participants selected were judged to be adequate sources of data needed to answer the research questions. In this study, the flipped classroom instruction was only implemented in this single group. Therefore, rich information could be obtained from this group of participants.

In order to explore the phases of teaching-learning in the EFL flipped classroom, the data was collected through observation in one semester of the academic year (FebruaryJune, 2015). The observation reported and discussed the activities and behaviors of students during the implementation of flipped classroom in the class and on the Blog outside the class.

Questionnaires were distributed to all 27 respondents at the end of the semester (June, 2015). Survey questionnaires consisted of a variety of close-ended questions including 2 check-list items and 15 five-level Likert scale items. Before distributing questionnaires to respondents, the researcher conducted a pilot test to measure the reliability of the instrument. The result of Cronbach's alpha was .862 and the questionnaires were considered as reliable. The questionnaires items were also checked by two educational technology experts for a validity or relevance with the context of the study.

In order to collect in-depth information about students' experiences in the EFL flipped learning, focus group discussion $(\mathrm{N}=10)$ and individual interviews $(\mathrm{N}=5)$ were conducted to collect the data. It provided students with the occasion to describe their experiences in their own words. The ten and five participants for the qualitative study were selected using a judgment sample. Furthermore, participants in this study were chosen based on their different academic backgrounds and the diversity in the classroom. The participants were classified by surface and deep learners. Simply categorized, deep learners were students who promoted active learning behaviors such as motivation, interaction, and engagement in the EFL classroom. On the contrary, 
surface learners were students with a lack of motivation, interaction, and engagement in the EFL flipped classroom or passive learning behaviors. Five deep learners and five surface learners were invited as participants in a focus group discussion and three active learners and two passive learners were invited to a personal interview.

In order to protect respondents' privacy and confidentially in this qualitative report, the researcher made data 'anonymous' by removing participants' names reported, changed to S1 to S10 for students in a focus group discussion and P1 to P5 for students in a personal interview. Data was analyzed in Convergent Parallel Design; quantitative and qualitative data analyzed together to compare and relate their findings (Creswell, 2013).

Ordinal data were usually interpreted as one score was higher than another and not the distance between the points. The data responses were analyzed in column charts with the percentage, Mean (M) and Standard Deviation (SD). The interview analysis of this study used a step-wise design described by Patton (2002). The process consisted of three steps: (1) Assemble the raw case; the interviews were transcribed by the researcher to get the print version of the interview, (2) Construct the case record; the raw data of students' motivation was classified in themes and edited by the researcher, (3) Report a final case; the result of interview discussion was reported descriptively according to their themes.

\section{FINDINGS}

To begin, this analysis was to identify students' familiarity with technological devices in teaching-learning activities. This analysis answered the research question 1: How familiar are students with technological devices in teaching-learning activities?

Checklist question reported that most students were familiar and already owned diverse technological tools such as computer desktop, laptops, Smartphone, iPhone, and iPads. It designated that $96 \%$ students have owned a laptop, $70 \%$ Smartphone, and $14 \%$ computer desktop. See the following Figure 1:

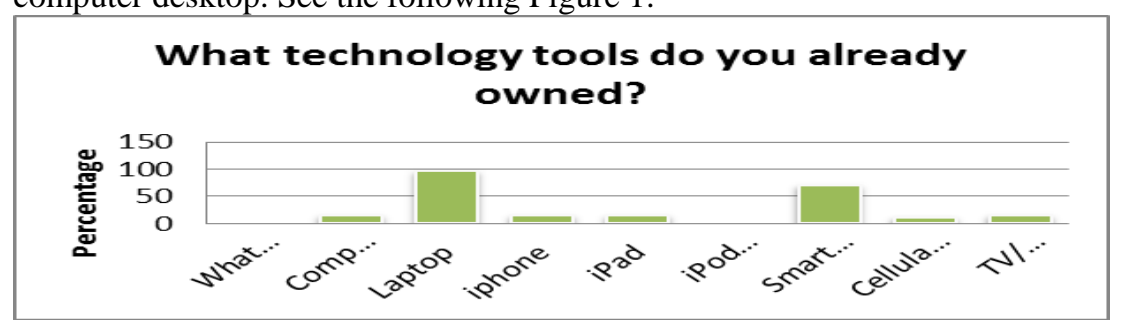

Figure 1

Technology deviced owned by college students

Checklist question also reported that various technological tools were used for learning activities outside of class hours. More than $81 \%$ of students preferred watching lesson videos from the laptop and $55 \%$ from the Smartphone (See the following Figure 2). By all means, findings showed that using technology tools for educational purposes was common among undergraduate students at the State Islamic University of Ar-Raniry. 


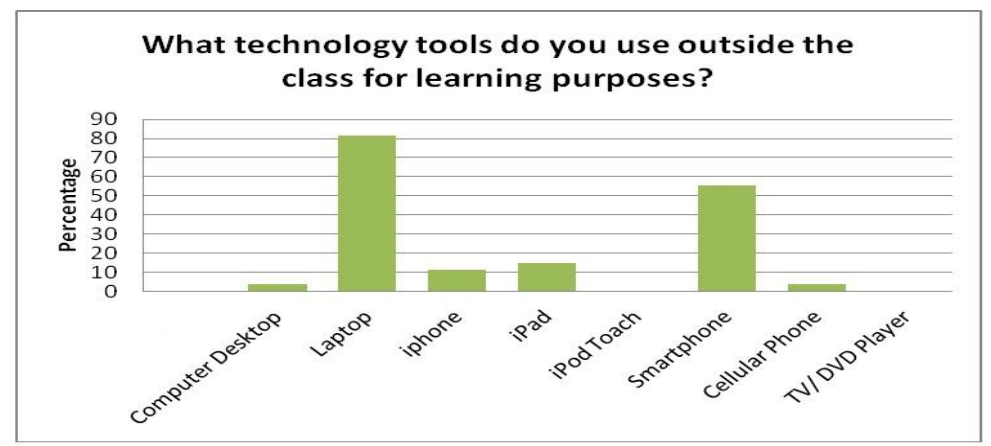

Figure 2

Technology device accessed outside the class for learning purposes

From the observation, the researcher discovered the procedures of implementing flipped classroom in teaching English. This analysis answered the research question 2: How do the instructors apply the flipped classroom in teaching English?

It records that face-to-face meeting in the classroom was conducted once a week and the duration was 1 hour and 40 minutes (100 minutes). Five steps had been implemented by an instructor in flipping English language class. First, the instructor distributed one movie trailer every week on the Blogger, the video trailer was adopted from YouTube. Overall, six movies had been shared during one semester. The duration of movie trailers was varied, the shortest video was 4:21 minutes and the longest was 8:15 minutes.

Second, students watched a movie trailer before coming to class independently. Third, when in the class, 40-minute was allocated for listening exercise. Fourth, 45-minute was allocated for conversation or storytelling activities, and fifth, 15-minute was allocated for interactive feedback session based on the movie trailers and topic discussion. The feedback was provided by instructor or students (Peer-evaluation).

Furthermore, Likert scale questionnaires, focus group discussion, and personal interview were used to explore students' experiences and perceptions of learning English in the flipped classroom. They were analysed by Convergent Parallel Design; quantitative and qualitative data analysed together to compare, relate and interpret the findings. The analysis shows that students have high percentages of positive perceptions regarding the flipped classroom instruction. Furthermore, several positive themes emerged during the discussion and personal interview. This analysis answered the research question 3: What are students' experiences and perceptions of learning English in the flipped classroom?

\section{Flipped classroom was more engaging than conventional classroom}

The questionnaires survey reported that more than $80 \%(\mathrm{M}=4.18, \mathrm{SD}=.833)$ of students acknowledged that the flipped classroom was more engaging than a traditional classroom. To strengthen this finding, student (S3) in focus group discussion compared his learning experience between the traditional classroom and the flipped classroom. He acknowledged: 
"Based on my experience learning in this class [flipped classroom] and previous class [conventional classroom], I could confidently say that this class is better than the previous one. This class is more fun and active, especially in classroom activities. All students looked active in the class and classroom activities were more focused on practice or English exercise rather than listening to lectures" (S3)

Others reported:

"In this class, we have more times to practice or exercise on English conversation and listening. Compare with my experience while learning English in other class [conventional], this class is better and I find something new here, more active and more practice." (S1)

Some students in personal interviews also acknowledged the positive sides of learning English in the flipped classroom compared to the conventional classroom, for example:

"I think this class is better than a non-flip class, here we have sufficient time to practice English conversation, speaking, listening and doing exercise in the class." (P3)

From the above excerpt, we could infer that students preferred learning in the flipped classroom because of engaging in classroom activities and had more occasions to practice English with peers.

\section{Students' enthusiasm for watching movie trailers}

The survey result reported that most students had positive perceptions toward the flipped movie trailers or videos. Findings showed that more than $90 \%(M=4.25$, $\mathrm{SD}=.712$ ) of students always watched movie trailers before coming to the class. Students (S2) and (S4) declared that they paid attention when watching the movie trailers, took notes, paused and replied according to their needs. Their statements were also in coherence with the survey result that using video lessons in the flipped classroom enabled them to pause, stop, rewind and fast-forward according to their learning needs $(\mathrm{M}=4.22, \mathrm{SD}=.751)$.

Regarding the duration of movie trailers, most students declared that both short and long movies were interesting. It was reported from survey items that more than $80 \%(\mathrm{M}=4.18$, $\mathrm{SD}=.833$ ) of students whether agreed or strongly agreed that a short duration of movie trailers was interesting. Also, more than $80 \%(\mathrm{M}=4, \mathrm{SD}=.784)$ of students positively responded that a long duration of movie trailers was interesting. In this study, video trailers provided by the instructor on Blogger had durations ranging from 4 to 8 minutes.

In term of movie trailers' duration, some students (S1, S4, P1, and P2) also acknowledged that both long and short movie trailers were interesting and fun. For example, student (S1) stated:

"It doesn't matter that the video is short or long, watching movie trailer is interesting and fun, it is not like learning in a serious condition with a serious video, it is like an entertainment." (S1), 
While a student (S4) continued, "Watching the movie trailer for English learning is fun, I like it, no matter short or long duration because it looks like an entertainment for me, I can watch the movie anytime I at home by using my mobile phone." (S4).

Student (P2) also stated:

"I will watch all videos because of interesting, watching a movie is my hobby, I like this way of learning, hopefully, courses in the next semester will also provide this kind of learning instruction." (P2)

From this report, we could infer that the attractiveness and interesting of video lectures played a very significant role in establishing students' engagement with the content they learn and all students' showed their preferences toward videos lectures.

\section{Enhancing peer interactions}

In term of interaction, most students acknowledged that the flipped classroom instruction could help in establishing a good interaction with peers in the classroom and after the class hours. While in the class activities, students could interact through faceto-face groups working together and while outside the class hours, they could interact online on the Blog by asking and answering questions. In this case, problem-solving and exchanging ideas were not only established through face-to-face during the class hours but also online outside of the class. The survey result also revealed that $85 \%(\mathrm{M}=4.14$, $\mathrm{SD}=.863$ ) of students declared that the flipped learning instruction enhanced students' peer interaction among students in-class and out-of-class times. Also, $81 \%(\mathrm{M}=4, \mathrm{SD}$ $=.733$ ) of students believed that using a Blog made them easier to interact with the others outside of the class. Observation on the Blog also shows that students actively interacted with peer to exchange idea and solve problem, see the following Figure 3:

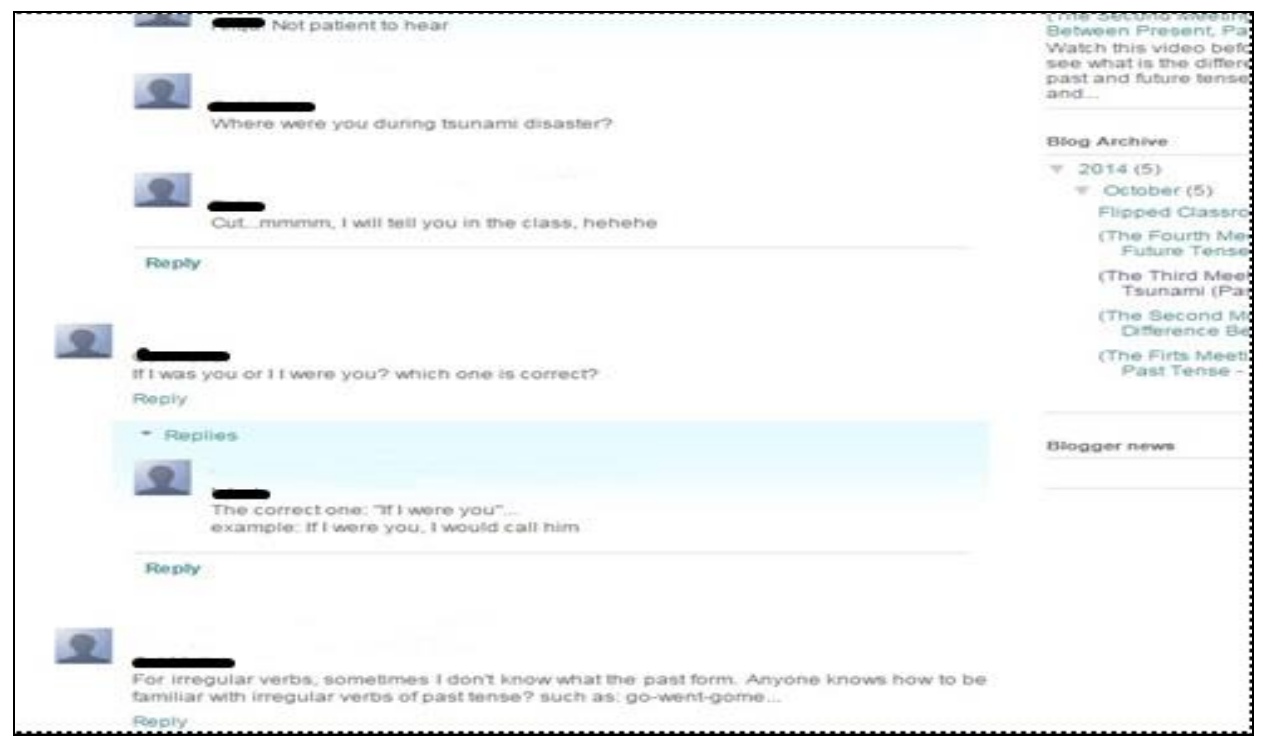

Figure 3

Students' online interaction on the Blog outside of the class times 
Another survey also reported that more than $80 \%(\mathrm{M}=4.11, \mathrm{SD}=.751)$ of students reported that through intensive interaction, students could learn a great deal from other students. It was in coherence with the statement of the student (S8): "I learn from other students, see their comments on the Blog and listen to their talks in the class." (S8)

Likewise, having more interactions will help passive students to be more active and learn from active students. Also, those students who didn't understand the subject could ask other students either in the classroom or online. Student (P4) in personal interview stated:

"I can discuss the movie trailer that I have watched with my friends online, sometimes when I don't understand the movie especially related to the idiom or slang words, I can ask and discuss my friends on the Blog." (P4)

Student (S7) mentioned the interactive activities in the classroom, he noted:

Student (S3) also declared that the flipped classroom gave her very positive impact in that she could communicate with others students through face-to-face and online. Based on the survey and interviews, we conclude that students perceived that the EFL flipped classroom could easily establish their intensive interaction whether in the class or outside the class times. Students' reports and arguments showed how important interaction and communication in the flipped classroom was.

\section{Students came to class prepared}

By flipping the class, students have more time to practice the subject outside the class and came to class prepared. Flipped classroom encouraged students to study intensively outside the class at their pace. The survey questionnaires reported that $85 \%(\mathrm{M}=4.22$, $\mathrm{SD}=.800$ ) of students agreed that the flipped classroom instruction gave them ample opportunities to prepare for in-class activities. Student (P5) in the interview acknowledged:

"I can prepare the subject outside the class and I become more confident in a group discussion." (P5)

While student (S9) in a focus group discussion stated:

"By watching movie trailers outside the class, I could prepare what I would discuss in the class in the next meeting, by doing this, I have a right to learn in my own way, for example, I could repeat watching video several times according to my need and I could study in my way." (S9)

Student (S8) agreed and mentioned:

"Yes, by watching videos outside the class, we can watch in our own ways, and we can study autonomously." (S8)

Again, their statements were consistently in coherence with the survey result, $8 \%(M=4$, $\mathrm{SD}=.832$ ) of students acknowledged that they were able to manage their own learning in the flipped classroom. 


\section{Students' engagement in classroom activities}

The impact of preparation on the subject outside the class had constructed students' engagement in the classroom activities through listening and speaking/storytelling exercise. The survey questionnaire reported that $81 \%(\mathrm{M}=4, \mathrm{~S}=.832)$ of students had participated and engaged in class activities. The survey also reported that students were confident in practicing their knowledge and were satisfied with the way English was taught through this instruction.

This instruction typically increased student collaboration, discussion, and performance activities. With a better use of class time activities for practicing English language, students were able to demonstrate their understanding and knowledge by exchanging idea and asking more questions, for example:

"When discussion activities in the class, I listen very carefully to my friends' explanation, then I can ask questions when I don't understand. In this class, students are not listening to a long lecture or taking a long note like in the traditional class, here we are practicing and participating in-class discussion."(S10).

\section{Students' obtaining immediate instructor's feedback}

The questionnaire survey reported that more than $88 \%(\mathrm{M}=4.18, \mathrm{SD}=.735)$ of students believed that instructor's feedback was very important in the flipped classroom. Immediate feedback from the instructor enabled participants to incorporate it into the learning process, as a student (S9) mentioned: "In the end of the class activities, the instructor always concludes the class with feedback, suggestion, and motivation; it is a good way of learning activities." (S9)

Other student stated: "Her [instructor] feedback makes me understand the subject," while student (S1) stated: "Yes, from this class, I like the role of instructor, she [instructor] acts as a jury, allows us to discuss with our friends, he listened and finally corrected us."

This theme indicated that many students believed that the role of the instructor in flipped classroom was very important to improve their learning through feedback. This finding consistently supported the previous survey result which stated: "The feedback given on my work helped me to improve." This statement elicited the strongest response from students, with $81 \%(\mathrm{M}=4.88, \mathrm{SD}=.751)$ of students positively responding to this statement.

\section{DISCUSSION AND RECOMMENDATION}

Analysis of the survey, focus group discussion, and personal interview reveal that almost all students were positive about the implementation of the flipped learning instruction in teaching-learning English. Students have more control on when and where they could engage with the content. They also have the ability to control the video lectures by pausing, rewinding, and fast forwarding when necessary. This study also reveals that 
most students acknowledged that the movie trailers provided by the instructor on the Blog were interesting and entertaining.

This study reported that the students had constructed their engagement in-class activities, this statement was in coherence with was noted by Kim, Kim, Khera, and Getman (2014) that the students will be more confident and active in classroom activities because they come to class prepared. In the flipped learning environment, students regulate the time of learning at their own pace and learn the new subject independently outside the class hours. Students could access the video lesson everywhere in convenient places such as coffee shop, bus, park, or home and they could use various learning devices to watch the video on the Blog such as a laptop, computer or Smartphone. The classroom activities also worked to develop students' critical thinking through a small group discussion.

Besides, students in this study have time to interact with classmates through the forum, group discussion, and other means. The research findings showed that most students acknowledged that the flipped classroom instruction supported the establishment of good communication with peers at any time. Zainuddin and Attaran (2015) declared that the flipped classroom implementation provides valuable time for student-student interaction outside of class via an online forum and face-to-face classroom meeting. This instruction affords ample opportunity for students to exchange knowledge, enhances higher order thinking skills, become more confident and engaged in classroom activities. Additionally, the finding also confirmed the testimony contributed by Kellogg and Smith (2009) that student-instructor interaction is also established in the flipped classroom, through this interaction, immediate feedback will be directly provided by the instructor for the learners. In term of learning a foreign language, Arslan and Şahin-Kızıl (2003) observed that numerous technology tools enable students to easily learn English everywhere and anytime without depending on the instructor as the center of knowledge.

Moreover, employing the flipped classroom instruction also contributes to a better understanding of technology use in teaching-learning activities; the instructor and students utilize various technology media in teaching-learning activities. Zainuddin and Halili (2016) claimed that the flipped classroom instruction becomes a new culture of learning in the 21 st century and has been implemented worldwide for various fields of study. The students and instructor in the flip-class may use various technological media in teaching-learning practice such as learning management systems, Web 2.0, online video lectures, online courses, or tutorials. In terms of using technology in learning a foreign language, there is no doubt that technology gives more advantages for students' learning. It means that technology uses in teaching language can establish students' interactive learning and transform the teaching-learning activity from being traditional to technology-based learning.

This study also reports that the practice of teaching-learning English language in the flipped classroom was in coherence with the theory of Bloom's Taxonomy for the cognitive domain (Bloom, 1956). The results showed that students in this study practiced "Knowledge" as the lowest level of cognitive work outside of class by reviewing the content autonomously. The students gain new information from the video 
lectures outside of the class hour or at home, and they attempted to understand the basic concepts and principles of the content they learned.

The second level was "Comprehension"; the students attempted to demonstrate their understanding, interpret the information and summarize what they had learned from the videos lectures. They also recorded notes to prepare what they would explain and ask in the class discussion. This level confirmed how the students' learned in the flipped classroom by firstly understanding the content at home and later discussing the content in the class.

Furthermore, when in the classroom activities, the students practiced the level of "Application", in this level of taxonomy, the students practice about what they had learned from the video. The students attempted to solve the problem with peers in the discussion forum.

The next level was "Analysis", in this level of Taxonomy; the students were able to resolve the problem and discover evidence to support problems' solution. It occurred when students began the discussion with peers, performed critical thinking, solved the problem, debated with friends, compared the answer with peers, and produced a summary. These activities had also improved students' engagements and interaction in classroom activities.

The fifth level is synthesis; the students had obtained new knowledge and idea after having a critical thinking or a debate in group activities. In this level, the students had understood the subject and problem they had discussed or debated. Reflected the previous students' report that their understanding was improved in the flipped classroom and they had known how to communicate and share what they had learned to others, this statements showed that the students had achieved the level of Synthesis in Taxonomy. The sixth level of "Evaluation" was also emerged in the flipped classroom practice where the instructor evaluated students' discussion and provided immediate feedback for their improvement. This activity had promoted students' opportunity to interact with the instructor whether individually or group.

In this study, the researcher concluded that the students had successfully reached six levels of cognitive domain of Taxonomy or achieved higher-level learning of Bloom's Taxonomy. "Knowledge" and "comprehension" as the lowest level of the cognitive domain were practiced independently outside of the class while the highest levels of the cognitive domain (application, analysis, synthesis, and evaluation) were practiced in the classroom. This finding was in coherence with the study reported by Nederveld and Berge (2015); the flipped classroom had constructed a student-centered learning environment, the students were actively involved in learning activities and achieving higher-level of cognitive Bloom's Taxonomy. Ravenscroft and Luhanga (2014) also reported that the flipped classroom model implemented in humanities and social science courses were statistically significant $(\mathrm{p}<0.05)$ improvements in higher-order thinking skills in the flipped classroom.

In contrast with the conventional classroom instruction, students' practice the lowest level of cognitive work (Knowledge and comprehension) in the class while other 
domains (Application, Analysis, Synthesis, and Evaluation) were practiced outside of class. The traditional classroom learning has always been traditionally practiced with the physical attendance to the class, the use of textbooks and paper examinations. Staker and Horn (2012) notice that the traditional university courses usually characterized as curriculum-based and lecture based teaching where the instructor acts as the central of knowledge. A course is organized by a curriculum provided through various materials and a number of lecture-based modules that are predetermined and sequenced. One-way lectures commonly practiced in the conventional class with more answers and discussions rather than problem-solving. Although the conventional classroom may benefit in a physical face-to-face interaction and low cost with no technological use, this instruction has a number of problems. For example, teaching and learning activities only focused on textbooks and lectures, students tend to be disengaged from active learning since they have a lack of time to express their abilities or performances in the class. Traditional learning tends to produce a low level of students' engagement and low attention to the subject they learn (Carini, Kuh \&Klein, 2006).

As this study only identified students' experiences and perceptions, a further study is recommended to examine students' learning effectiveness in the flipped learning environment. This study encourages the English instructors to implement the flipped learning instruction in their teaching practices. Moreover, it is potentially implemented in various fields of study at every University in Indonesia and worldwide. Furthermore, this study has a small number of samples in responding questionnaires and should be evaluated and continue in the further studies. Focus group discussion and personal interview for data generation were also voluntary with a small sample $(\mathrm{N}=10$ and $\mathrm{N}=$ 5 ). Those who were culturally timid and passive in class activities may not have been confident enough to volunteer themselves in the interviews sessions. Hence, there probably remain other views which were not included. The instructors may also record and design the video lectures by themselves and the contents must be entertaining which includes some elements such as animation, cartoon, and music. Finally, policymakers and practitioners should seriously examine the research on the flipped classroom in order to transform the traditional teacher-students centered to student-teacher centered learning environment. Bolstered by the findings of this study, policymakers and practitioners should consider implementing flipped classroom in higher education. This learning environment has the potential to promote student-cantered and a new culture of pedagogy in higher education.

\section{REFERENCES}

Bergmann, J., \& Sams, A. (2014). Flipped learning: Maximizing face time. $T+D$ Magazine, 68(2), 28-31.

Bloch, J. (2002). Student/teacher interaction via email: The social context of Internet discourse. Journal of Second Language Writing, 11(2), 117-134.

Bloom, B. S. (1956). Taxonomy of educational objectives: The classification of educational goals: Cognitive Domain. Longman. 
Carini, R. M., Kuh, G. D., \& Klein, S. P. (2006). Student engagement and student learning: Testing the linkages. Research in higher education, 47(1), 1-32.

Creswell, J. W. (2013). Research design: Qualitative, quantitative, and mixed methods approaches. Sage publications.

Davies, R. S., Dean, D. L., \& Ball, N. (2013). Flipping the classroom and instructional technology integration in a college-level information systems spreadsheet course. Educational Technology Research and Development, 61(4), 563-580.

De Jong, R. J., Van Tartwijk, J., Verloop, N., Veldman, I., \& Wubbels, T. (2012). Teachers' expectations of teacher-student interaction: Complementary and distinctive expectancy patterns. Teaching and Teacher Education, 28(7), 948-956.

Driscoll III, T., \& Petty, K. (2013). Student-driven education with flipped learning and 20-time. Practical applications and experiences in $K-20$ blended learning environments, 120-135.

Halili, S. H., \& Zainuddin, Z. (2015). Flipping the Classroom: What We Know And What We Don't. The Online Journal of Distance Education and e-Learning, 3(1), 28-35.

Hamre, B., Hatfield, B., Pianta, R., \& Jamil, F. (2014). Evidence for general and domain-specific elements of teacher-child interactions: Associations with preschool children's development. Child development, 85(3), 1257-1274.

İlin, G., Kutlu, Ö., \& Kutluay, A. (2013). An action research: Using videos for teaching grammar in an ESP class. Procedia-Social and Behavioral Sciences,70, 272-281.

Johnson, L., Becker, S., Estrada, V., \& Freeman, A. (2014). NMC Horizon Report: 2014 Higher Education Edition (Rep.).

Kellogg, D. L., \& Smith, M. A. (2009). Student-to-student interaction revisited: A case study of working adult business students in online courses. Decision Sciences Journal of Innovative Education, 7(2), 433-456.

Kim, M. K., Kim, S. M., Khera, O., \& Getman, J. (2014). The experience of three flipped classrooms in an urban university: an exploration of design principles. The Internet and Higher Education, 22, 37-50.

Nederveld, A., \& Berge, Z. L. (2015). Flipped learning in the workplace. Journal of Workplace Learning, 27(2), 162-172.

Ravenscroft, B., \& Luhanga, U. (2014, June). Developing Employability Skills in Humanities and Social Sciences Using the Flipped Model. In ICEL2104-Proceedings of the 9th International Conference on e-Learning: ICEL 2014 (p. 142). Academic Conferences Limited.

Scott, T. (2003). Bloom's taxonomy applied to testing in computer science classes. Journal of Computing Sciences in Colleges, 19(1), 267-274. 
Staker, H., \& Horn, M. B. (2012). Classifying K-12 Blended Learning. Innosight Institute.

Teclehaimanot, B., \& Hickman, T. (2011). Student-teacher interaction on Facebook: What students find appropriate. TechTrends, 55(3), 19-30.

Wan, J., \& Tan, B. H. (2011). WeBlogs for English Language Learning: Students' Perceptions. Turkish Online Journal of Distance Education, 12(4), 115-132.

Wang, S., \& Heffernan, N. (2010). Ethical issues in Computer-Assisted Language Learning: Perceptions of teachers and learners. British Journal of Educational Technology, 41(5), 796-813.

Zainuddin, Z., \& Attaran, M. (2015). Malaysian students' perceptions of flipped classroom: a case study. Innovations in Education and Teaching International, 53(6), 660-670.

Zainuddin, Z., \& Halili, S. H. (2016). Flipped Classroom Research and Trends from Different Fields of Study. International Review of Research in Open and Distributed Learning, 17(3), 313-340.

\section{Turkish Abstract \\ Üniversite Birinci Sınıf Öğrencilerinin Teknolojik Olarak Zenginleştirilmiş Sınıf Ortamında Yabancı Dil Olarak İngilizce Öğrenme Deneyimleri: Endonezya'da Bir Durum Çalışması}

Mevcut çalışma, Endonezya'daki İslam Negeri Ar-Raniry Üniversitesi'ndeki birinci sınıf öğrencilerinin teknolojik olarak zenginleștirilmiş bir sınıftaki yabancı dil olarak İngilizce öğrenme deneyimlerini tanımlamayı amaçlamaktadır. Bu çalışmanın örneklemini iki İngilizce kursuna katılan kayıtlı 27 öğrenci oluşturmaktadır. Veriler anket çalışmaları, odak grup görüşmeleri, bireysel görüşmeler ve gözlemler gibi farklı kaynaklardan toplanmıştır. Nicel veriler yüzde, ortalama ve standart sapma olarak sütun grafiklerinde gösterilirken, görüşme analizlerinde ise Patton(2002) tarafindan kullanılan aşamalı dizayn tercih edilmiştir. Süreç 3 aşamadan oluşmaktadır: (1) Ham veriyi bir araya getirme, (2) Durumun kayıt altına alma ve (3) Son durumu raporlama. Sonuçlar teknolojik açıdan zenginleştirilmiş sınıf ortamlarının uygulamalı alıştırmalar ve akran alıştırmaları ile bağlantılı olduğunu göstermiştir. Bu eğitim öğrencilere sınıfa gelmeden önce içeriği öğrenmede artan bir istek kazandırmış, öğrenciler arasında daha fazla etkileșim firsatlarının doğmasını sağlamış, sınıf, eğitimcinin dönütlerine hazır hale gelmiştir. Sonuç olarak kategoriler öğrencilerin çoğunun teknolojik açıdan zenginleştirilmiş sınıf ortamlarına karşı son derece olumlu olduğunu göstermiştir. Bu çalışmada araştırmacı, öğrencilerin 6 bilişsel alan seviyesini veya Bloom's Taksonomisinin üst düzey öğrenmelerini başarılı bir şekilde gerçekleştirdiklerini ifade etmiştir.

Anahtar Kelimeler: teknolojik olarak zenginleştirilmiş sınıf, yabancı dil olarak İngilizce öğrenme (EFL) Bloom Taksonomisi, deneyim, etkileşim, video konferans 


\section{French Abstract \\ Les expériences d'Étudiants universitaires de Première année dans l'EFL Ont donné un petit coup à Salle de classe: une Étude de cas en Indonésie}

L'étude présente a eu pour but d'identifier le premier apprentissage des étudiants universitaires d'année et les expériences dans un EFL la salle de classe donnée un petit coup à l'Université Islamique D'état d'Ar-Raniry en Indonésie. 27 étudiants qui ont inscrit dans l'anglais 2 cours ont participé comme les échantillons de cette étude. Les données ont été rassemblées de sources diverses incluant des enquêtes(des vues générales) de questionnaire, la discussion de groupe de discussion, l'entretien(interview) individuel et l'observation. Les réponses de données quantitatives ont été analysées dans des histogrammes avec le pourcentage, l'Écart-type et Moyen tandis que l'analyse d'entretien (interview) a utilisé un design(une conception) point par point décrit par Patton (2002). Le processus a consisté en trois étapes: (1) Assemblent le cas brut; (2) Construisent le rapport de cas et (3) Rapportent un cas final. Des résultats désignés que les étudiants ont engagé dans l'EFL l'environnement de salle de classe donné un petit coup par des activités sur le terrain et le pair le travail. Cette instruction aussi a avec succès amélioré l'enthousiasme des étudiants pour apprendre le contenu avant l'arrivée à la classe, pourvu que plus d'occasions pour l'interaction parmi des pairs, est venu à la classe préparée et a obtenu les retours d'information de l'instructeur immédiat. Tout compte fait, les catégories ont révélé que la majorité d'étudiants a perçu la salle de classe donnée un petit coup fortement positive. Dans cette étude, le chercheur a conclu que les étudiants avaient avec succès réalisé six niveaux de domaine cognitif de Taxonomie ou l'apprentissage de niveau plus haut de la Taxonomie de Bloom.

Mots Clés: salle de classe donnée un petit coup, EFL, la Taxonomie de Bloom, expérience, interaction, engagement, cours vidéo

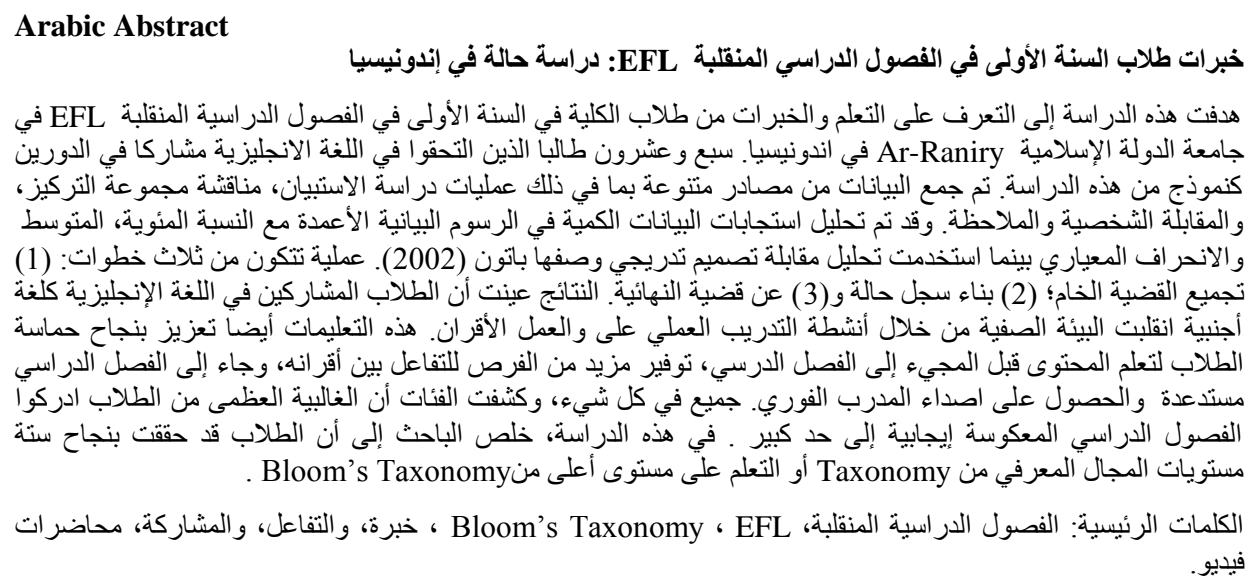




\section{German Abstract \\ Erstes Studium der Studenten in der EFS flippte Klassenzimmer: Eine Fallstudie in Indonesien}

Die vorliegende Studie zielte darauf ab, das erste Jahr College-Studenten Lernen und Erfahrungen in einem EFL flippte Klassenzimmer an der Staatlichen Islamischen Universität von Ar-Raniry in Indonesien zu identifizieren. 27 Studenten, die in Englisch 2 Kurs teilgenommen als Proben dieser Studie. Die Daten wurden aus verschiedenen Quellen gesammelt, einschließlich Fragebogenumfragen, Fokusgruppendiskussion, individuelle Befragung und Beobachtung. Die quantitativen Datenreaktionen wurden in Säulendiagrammen mit dem Prozentsatz, Mittelwert und Standardabweichung analysiert, während die Interviewanalyse ein schrittweises Design verwendete, das von Patton (2002) beschrieben wurde. Das Verfahren bestand aus drei Schritten: (1) Zusammensetzen des Rohkörpers; (2) Erstellen der Falldatensätze und (3) Melden Sie einen endgültigen Fall. Ergebnisse bezeichnet, dass Studenten in der EFS gespielt Klassenzimmer Umgebung durch praktische Aktivitäten und Peer-Arbeit. Diese Anweisung auch erfolgreich erhöht Studenten die Begeisterung für das Lernen der Inhalte, bevor sie in die Klasse, sofern mehr Chancen für die Interaktion zwischen Kollegen, kam zu Klasse vorbereitet und erhielt sofortige Lehrer Feedbacks. Alles in allem zeigten die Kategorien, dass die Mehrheit der Studenten die blätterte Klassenzimmer sehr positiv wahrgenommen. In dieser Studie kam der Forscher zu dem Schluss, dass die Schüler hatten erfolgreich erreicht sechs Ebenen der kognitiven Bereich der Taxonomie oder übergeordnetes Lernen der Bloom-Taxonomie.

Schlüsselwörter: flippte klassenzimmer, EFL, Bloom Taxonomie, erfahrung, interaktion, engagement, video-vorträge

\section{Malaysian Abstract \\ Pengalaman Pelajar Kolej Tahun Pertama dalam EFL Flipped Classroom: Satu Kajian Kes di Indonesia}

Kajian ini bertujuan untuk mengenal pasti pembelajaran dan pengalaman pelajar kolej tahun pertama dalam EFL Flipped Classroom di Universiti Islam Negeri Ar-Raniry di Indonesia. 27 pelajar yang mendaftar dalam bahasa Inggeris 2 mengambil bahagian sebagai sampel kajian ini. Data yang telah dikumpulkan daripada sumber-sumber yang pelbagai termasuk kaji selidik soal selidik, perbincangan kumpulan fokus, temuduga individu dan pemerhatian. Maklum balas data kuantitatif dianalisis dalam carta lajur dengan peratusan, min dan sisihan piawai manakala analisis temu bual yang digunakan reka bentuk yang digambarkan oleh Patton (2002). Proses ini terdiri daripada tiga langkah: (1) mengumpul kes mentah; (2) bina rekod kes itu dan (3) laporkan kes akhir. Keputusan menetapkan bahawa pelajar yang terlibat dalam EFL Flipped Classroom persekitaran bilik darjah melalui aktiviti amali dan rakan sebaya. Arahan ini juga berjaya meningkatkan semangat pelajar untuk belajar isi kandungan sebelum datang ke kelas, menyediakan lebih banyak peluang untuk berinteraksi dalam kalangan rakan-rakan, datang ke kelas dengan maklum balas segera daripada pengajar. Secara keseluruhannya majoriti pelajar dilihat sangat positif dalam Flipped Classroom. Dalam kajian ini, penyelidik membuat kesimpulan bahawa pelajar telah berjaya mencapai enam peringkat domain kognitif Taksonomi Bloom.

Kata Kunci: flipped classroom, EFL, Taksonomi Bloom, pengalaman, interaksi, penglibatan, video ceramah 


\section{Russian Abstract \\ Опыт Изучения Английского как Иностранного на Первоее Курса в Технологически Обогащенном Классе: Тематическое Исследование в Индонезии}

Настоящее исследование направлено идентифицировать первый год студенчества знаний и опыта в английского как изучения иностранных языков (EFL) классе переворачивается в Государственном Исламском университете Ar-Raniry в Индонезии. 27 студентов, которые поступили в английском языке 2 курс участвовал качестве образцов из данного исследования. Данные были собраны из различных источников включая анкетирование, фокус групповая дискуссия, и индивидуальные интервью и наблюдения. Количественные данные ответах были проанализированы в гистограмм с процентом, Среднее и стандартное отклонение в то время как анализ интервью использовал дизайн ступенчатым, описанный от Паттон (2002). Процесс состоял из трех этапов: (1) Собирать сырой случай; (2) Построить кейс запись и (3) Отчет окончательный кейс. Результаты обозначены что студенты участвующие в английского как изучения иностранных языков (ECL) переворачивается классе среду через практические занятия и сверстников работы. Эта инструкция также успешно усилить энтузиазм студентов для обучения содержание до прихода к классу, при условии, больше возможностей для взаимодействия среди сверстников, пришел в класс, подготовленный и полученный обратные связи немедленного инструктора. В целом, категории показало, что большинство студентов воспринимается перевернутую класс очень позитивно. В этом исследовании, исследователь пришел к выводу, что студенты были успешно достигнуты шесть уровней когнитивной области систематики или обучения более высокого уровня систематики Блума.

Ключевые Слова: перевернутый класс, английского как изучения иностранных языков (EFL), Таксономия Блума, опыт, взаимодействие, видеолекции 